\title{
A Non-Destructive Survey of Tombs in the Chapel of St. Barbara on Modla Hill (cadastral district of Buchlovice)
}

\author{
Vladimír Hašek ${ }^{1}$, Tomáš Mořkovský ${ }^{2}$, Jiří Šindelářr ${ }^{3}$ Jan Tomešek ${ }^{1}$ \\ ${ }^{1}$ Isolines, spol. s r.o., Došlíkova 3, 63600 Brno \\ ${ }^{2}$ Department of Anthropology, Faculty of Science, Masaryk University, Vinařská 5, 60300 Brno \\ ${ }^{3}$ Naše historie, o.s., Měšická 1724, 39002 Tábor
}

Received $5^{\text {th }}$ of December 2012; accepted $20^{\text {th }}$ of March 2013

\begin{abstract}
NEDESTRUKTIVNÍ PRŮZKUM HROBEK V KAPLI SV. BARBORY NA VRCHU MODLA (K. Ú. BUCHLOVICE)
ABSTRAKT V interiéru kaple sv. Barbory na vrchu Modla v blízkosti hradu Buchlova byl proveden nedestruktivní průzkum geofyzikální metodou GPR a prohlídka lokalizovaných nehomogenit kamerovým systémem. Výzkumy umožnily přesnou lokalizaci a zjištění současného stavu hrobek některých majitelů buchlovského panství. Detekovány byly také relikty zdiva z původního středověkého sakrálního objektu situovaného ve střední části kaple. Použití nedestruktivních metod umožnilo optimální řešení výzkumu z hlediska získání velkého množství informací v krátkém čase a bez velkých finančních nákladů.
\end{abstract}

KLÍČOVÁ SLOVA georadar; vizuální průzkum; hrobka; zdivo; dokumentace nepř́stupného podzemí

ABSTRACT The interior of the Chapel of St. Barbara near Buchlov Castle was geophysically surveyed using a non-destructive GPR method and the localized inhomogeneities were consequently inspected by a camera system. These procedures made possible precise localization and determining of the current state of the tombs of certain Buchlov estate owners. They also indicated the relics of the walls of the original Medieval religious structure which was situated in the central part of the sanctuary. A combination of these two methods provides an optimal solution to the task in terms of obtaining a significant number of information, saving time, and also being economically reasonable.

KEY WORDS georadar; visual survey; tomb; masonry; documentation of the inaccessible underground

\section{INTRODUCTION}

In connection with possible reconstruction of the tombs in the modern-age funeral Chapel of St. Barbara (cadastral district Buchlovice), non-destructive exploratory research was carried out in the interior of the building in the fall of 2011 and in the spring of 2012.

In the first phase a geophysical prospection was performed by Isolines s.r.o (ltd.) on October $10^{\text {th }}, 2011$ (Hašek - Tomešek 2011) and followed by the inspection of a number of the structures discovered by a camera system belonging to Naše historie o.s. (Our History - civic association) from Tábor.
The exploratory research was performed at the request of the Buchlov Castle management and in cooperation with the Department of Anthropology, Faculty of Science, Masaryk University, Brno.

The main objective of this work was to provide more detailed information about the positions and sizes of the individual tombs and the current state of the material stored inside them. The geophysical prospection was also aimed at revealing the extent of possible relics of the foundation walls of the original extinct medieval chapel, or other related structural elements. The aim of the prospecting was thus to provide a more thorough basis for possible excavation of the tombs, or other ad- 


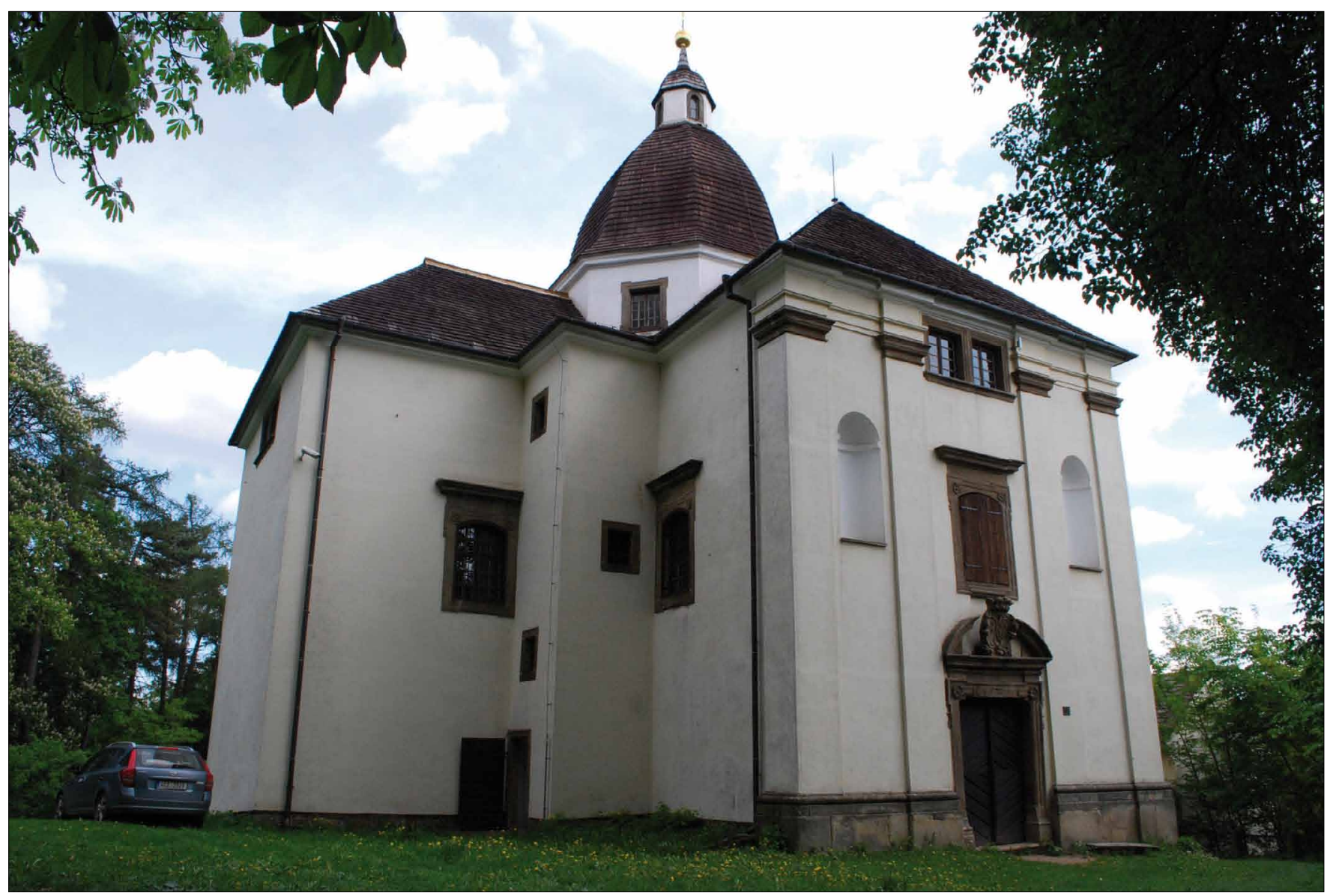

Fig. 1. Buchlov - the Chapel of St. Barbara: view of the religious building from the north-west.

ditional information in the examined area of the chapel.

To address the individual sub-tasks, the georadar (GRP) method was applied, and subsequently the above-mentioned visual exploration was also utilized. The results of these methods, previously employed in the measurement of similar issues at different localities, such as Hašek, Glisníková 2005; Hašek et al. 2008; Hašek, Unger 1997; 2001; 2005; 2010, showed that their use in the present case is appropriate. The use of these methods made possible the obtaining of more detailed information without major disruption of the investigated situation and with relatively low financial costs (Hašek 1999).

\section{A BRIEF OVERVIEW OF THE GEOLOGICAL CHARACTERISCTICS OF THE SITE}

The wider area of the chapel of St. Barbara belongs, according to the Regional division of the Czech Republic (Czudek 1973) to Chřiby, into a subunit of the Stupavská Highland, consisting of the rocks of the Magura flysch of the Račany Unit, showing considerable facial changes, and also of Quaternary cover in the overlying stratum.

The pre-Quaternary subsoil (Paleogene) is represented, according to geological mapping, by the youngest stratigraphic unit of the Magura group of nappes - the Zlín Formation. In its upper part, the Vsetín layers from the middle and upper Eocene are a significant element. It is a typical flysch with a predominance of olive green calcareous claystones alternating with light grey calcareous sandstones with glauconite (Chlupáč et al. 2011, 339).

The Quaternary blankets are primarily represented by mechanical wastes of various grain size compositions which originated in the mild and glacial climate on flysch rocks.

\section{AN OUTLINE OF THE HISTORY OF THE RELIGIOUS BUILDING}

The chapel of St. Barbara (Fig. 1) is located at the top of Modla ("Idol") hill approximately $0.6 \mathrm{~km}$ north-east of Buchlov Castle. It was completed in 1673 on the site of an earlier medieval stone chapel of the same dedication from the $13^{\text {th }}$ century. Traces of settlement of this locality, however, reach back to the Eneolithic period.

The owner of the Buchlov estate at the time Hanuš Zikmund Petřvaldský built this chapel. It was constructed in the popular at the time style of late Moravian Mannerism between the periods of the Renaissance and the Baroque. 
Four tombs were built under the cross-shaped building with a central dome (Samek 1994, 317). The remains of a number of the owners of the estate of the Petrvald and Berchtold family are deposited here - i. e. the remains of the family members who have lived at the Buchlovice chateau from 1738 until 1945.

The main chapel altar was created at the end of the $17^{\text {th }}$ century and at the beginning of the $18^{\text {th }}$ century. On the chapel walls there are posthumous portraits of the Berchtold family members from the second half of the $19^{\text {th }}$ century. Tombstones are also placed along the walls of the chapel. The oldest one is from the year 1580 and belongs to Anna Šviková from Lukonosy, one of the younger tombstones is dedicated to the last Petřvald male descendant Jan Nepomuk. Other tombstones belong to the Berchtolds - Leopold I ( $† 1809)$, Zikmund I ( $\uparrow 1869)$, his wife Ludmila $(\dagger 1869)$ and their daughter Walburga. The tombstone of Zikmund II ( $\uparrow 1900)$ and Josefina Berchtold is also significant.

The Petryvald family had the intention of founding a monastery for monks from the order of the Holy Trinity, or Trinitarians, in the vicinity of the chapel. However, they never proceeded with the construction (Hrdý - Kořínek - Žižlavský 2005, 29). A fire damaged the chapel in 1896 which consequently further deteriorated. It was transferred, based on presidential decrees, to the ownership of the Czechoslovak state in 1945. Extensive renovation of its interiors was carried out in the second half of the the 1950s. The chapel was plastered from the outside, its interior was painted and fitted with security devices and lighting at the end of the 1990s.

The tradition of pilgrimages to this place was renewed in the 1990s with them taking place (with certain breaks) on feasts of the Holy Trinity and the Assumption of Virgin Mary up to the present day (Hrdý - Kořínek - Žižlavský 2005, 29).

\section{METHODOLOGY OF THE FIELDWORK}

\section{Geophysical prospecting}

In the interior of the examined building, 44 mutually perpendicular profiles with a total length of $295.8 \mathrm{~m}$ were measured over an area of approximately $230 \mathrm{~m}^{2}$.

The routes of the individual geophysical profiles were conducted in order to be approximately perpendicular to the expected course of the investigated structures, i.e. in the N-S and $\mathrm{E}-\mathrm{W}$ direction.

To address the issues outlined in the introduction, soil radar (GPR, georadar) was used, the apparatus RAMAC/GPR X 3M Geoscience Mala (Sweden), a shielded $250 \mathrm{MHz}$ antenna, with a depth range of approximately $3-4 \mathrm{~m}$. The antenna was moved on profiles ca $1 \mathrm{~m}$ from one other continuously on the surface of the tile floor. The trace interval was $5 \mathrm{~cm}$.

The result of the GPR measurement on the individual profiles (PF 1 to 24 and PF 23 to 44) are radarograms (see example Fig. 2) which shows the time of arrival of the waves since the time $r$ (sending the electromagnetic pulse). Successful application of the method is based on the existence of different permitti-

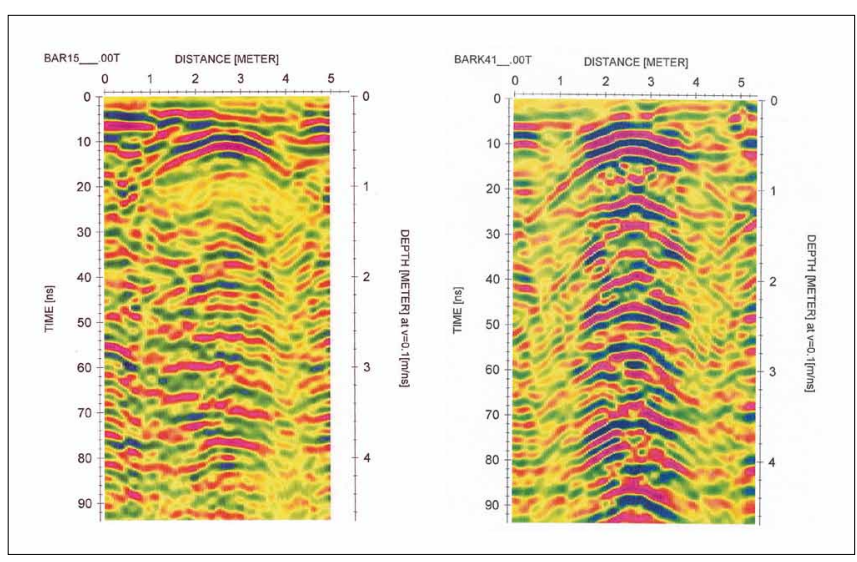

Fig. 2. Sample of radarograms from the tomb of the Petrrvald family (BAR 15) and the old tomb of the Berchtold family (BAR 41).

vities $(\mathrm{Sr})$ and specific resistances $\left(\mathrm{r}_{\mathrm{z}}\right)$ of the individual layers of the inhomogeneities.

If $S$ is known, the depth of the reflecting interfaces can be determined from the time of arrival of the reflected electromagnetic wave. As there was no additional information available regarding the thicknesses and lithological division of the anthropogenic layer or about additional Quaternary covers, a fictive depth of the Quaternary basis was considered $\left(\mathrm{v}_{\mathrm{r}}=\right.$ $0.10 \mathrm{~m} / \mathrm{ns}$ ).

Local inhomogeneities (walled tombs, graves - hollow or half-buried, relics of masonry, stone positions, steps, etc.) apperar as multiple reflections of electromagnetic waves in the form of curves similar to half hyperbolas placed under one other, with different widths and orientation (see Fig. 2).

\section{Visual survey}

A visual survey of the inaccessible underground spaces under the chapel of St. Barbara was carried out based on the results of the geophysical prospection on May 10, 2012. Two underground tombs were explored and documented in detail, the tomb of the Petrvald family under the southern wing of the chapel and the old tomb of the Berchtold family under the eastern wing of the chapel (Fig. 3). A prototype of an exploratory mini-probe was used for the survey and documentation. It was constructed in 2005 to explore the ancient royal tomb at the Prague Castle (Maříková-Kubková et al. 2005) and improved during the implementation of the project "A survey of the inaccessible underground in historic buildings" in 2007-2011. The exploratory probe consists of sensitive cameras, a laser rangefinder and incremental detectors. Moreover, it can be additionally equipped with a device for sampling (Fig. 4).

The existence of two large underground tombs was confirmed and explored in detail by this exploratory mini-probe. Penetration into the tomb of the Petrvalds (under the eastern wing of the chapel) was undertaken through the ventilation window in the east wall of the chapel. Apart from the massive stone sarcophagus, the tomb is primarily filled with debris, boards, remains and waste, thrown into the underground by 


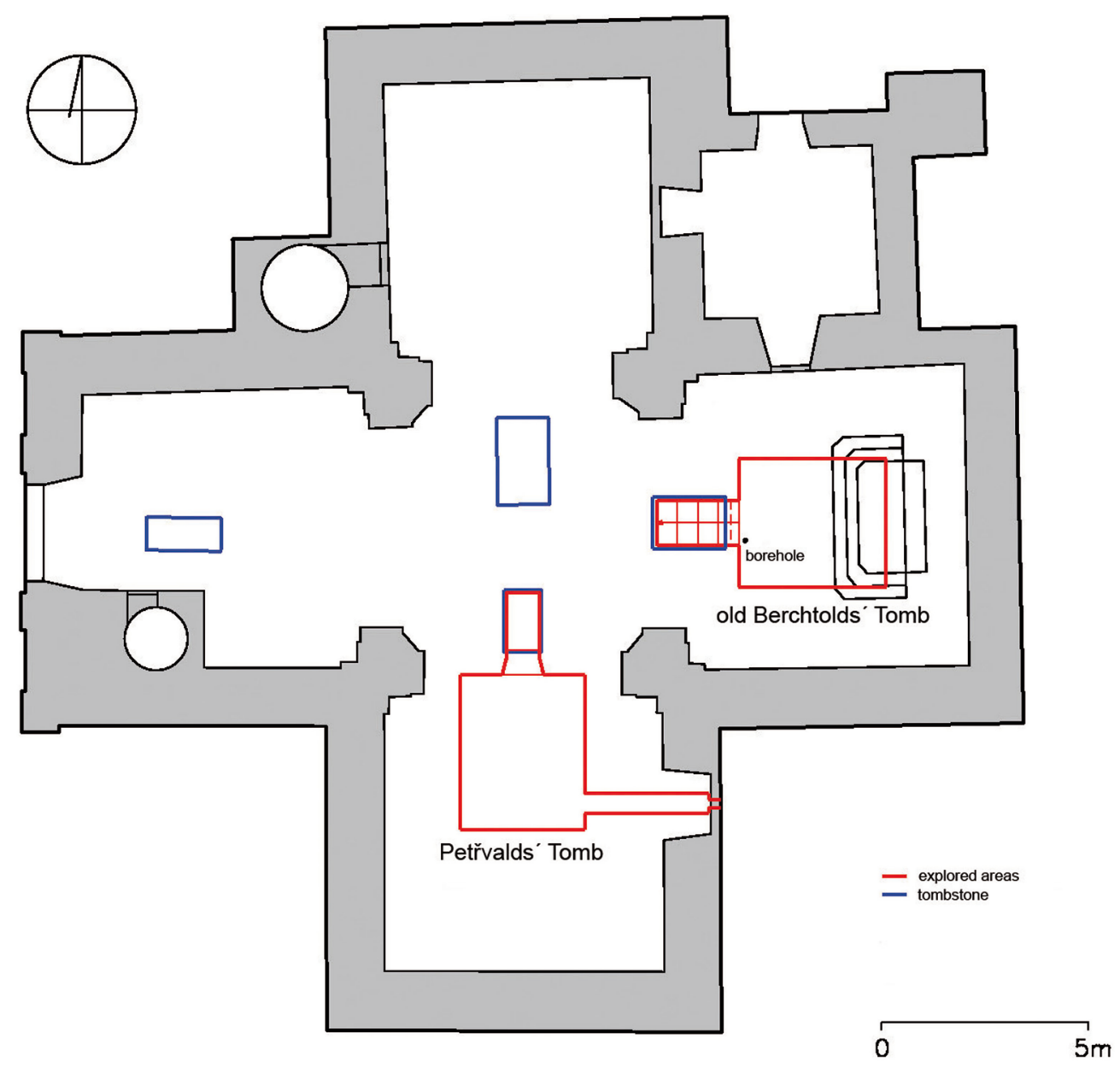

Fig. 3. Buchlov - the Chapel of St. Barbara. The ground plan of the tombs explored visually on May 10, 2012

this particular vent. There is no free access into the ancient tomb of the Berchtolds at present. For the needs of the survey, a $3 \mathrm{~cm}$ wide exploratory borehole was conducted at a point recommended by geophysics. The south of the tombstone (in the chapel floor) a burial chamber with seven burials was documented in detail. Three burials were identified with particular persons (Leopold Franz Xaver Berchtold, Sigismund I. Berchtold and Ludmila Berchtold, née Vratislav, of Mitrovice) thanks to the found authenticas.

\section{RESULTS OF THE NON-DESTRUCTIVE METHODS}

\section{Geophysical prospection}

Several areal and linearly oriented indications of subsurface inhomogeneities were identified in the interior of the chapel of St. Barbara by a thorough interpretation of the geophysical data in the form of a correlation diagram (Fig. 5). A number of the major inhomogeneities are recommended for verification, where possible, by several shallow wells (depth max. $1-1.5 \mathrm{~m}$ ) and by subsequent inspection with a camera system.
On the basis of the GPR, two major interfaces of reflected electromagnetic waves can be observed on a number of the measured profiles. They are located at times $\mathrm{t}_{1}=10-12 \mathrm{~ns}$ and $\mathrm{t}_{2}=38-44$ ns. Due to a, in all probability, gradual lithological transition between the anthropogenic layer and the Quaternary wastes, the first interface can represent landfill material with a maximum thickness of ca $0.5-0.6 \mathrm{~m}$., while the second one could be a certain fictive interface between a layer of Quaternary sandy-loamy wastes and the surface of weathered and partly weathered flysch rocks, whose relief is here at depths of ca $1.8-2.2 \mathrm{~m}\left(\mathrm{v}_{\mathrm{r}}=0.10 \mathrm{~m} / \mathrm{ns}\right)$.

A number of anomalies identified in the interpretation of the results of the geophysical works can be assigned to various tombs of different sizes ( 1 to 5 ) or to the possible foundation masonry of an older, now defunct medieval religious building, or to other architectural elements related to the above structures. The tops of all of these local inhomogeneities, as mentioned above, are concentrated at depths of ca 0.6 to $1.2 \mathrm{~m}$. Their widths vary between 1.0 to $2.0 \mathrm{~m}$, the basis ca 1.7 to $2.0 \mathrm{~m}$.

Four known entrances into the individual walled tombs are 


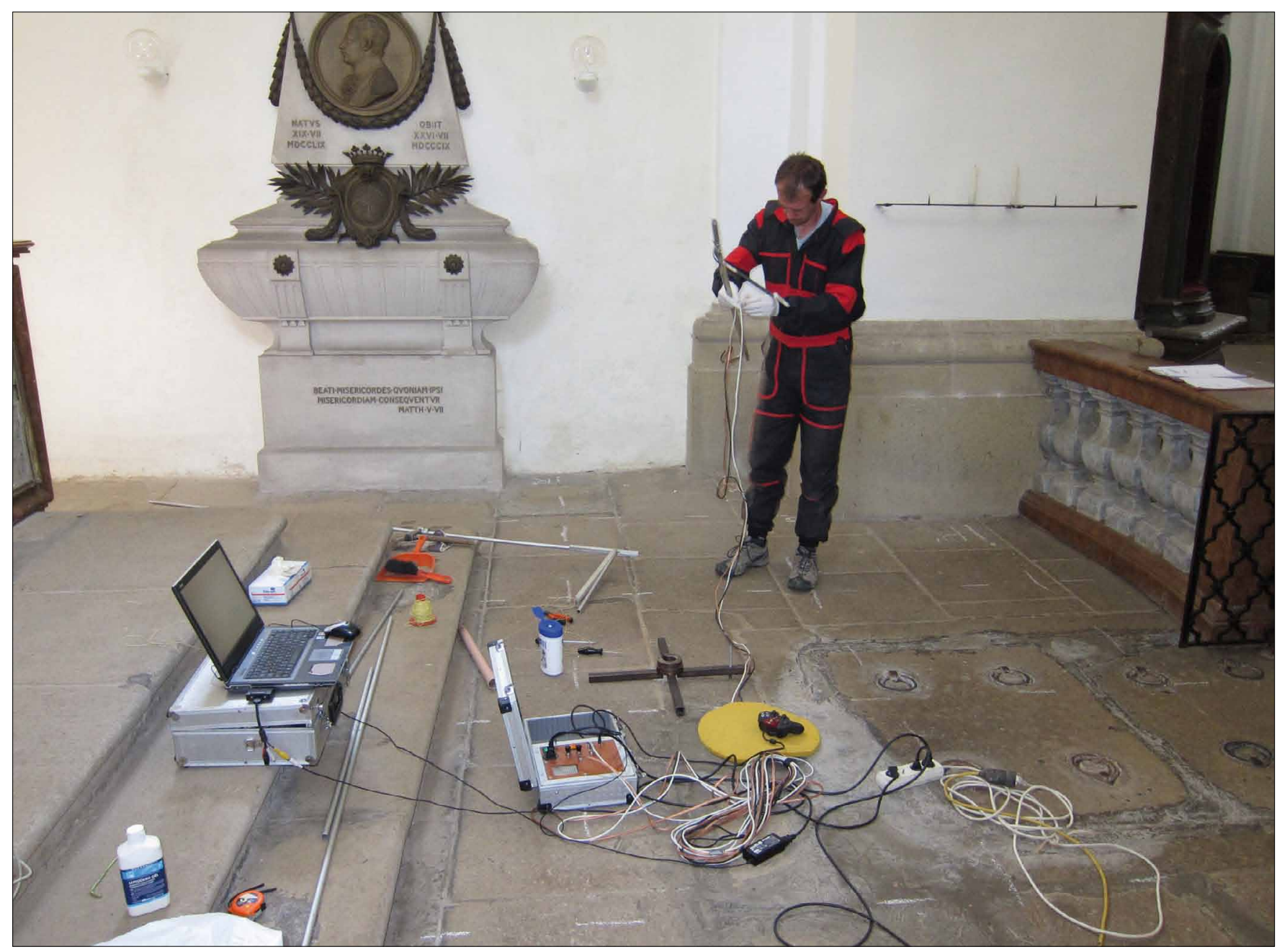

Fig. 4. Buchlov - the Chapel of St. Barbara: preparation of the miniprobe for the visual survey, May 10, 2012.

apparent in the chapel floor from the available documentary materials (marked 1 to 4 ) and also the ground plan of the larger newer tomb (5) (Fig. 6).

A relatively small tomb in the western wing of the chapel has geophysically interpreted dimensions of approximately $2.3 \times 1.2 \mathrm{~m}$. It is therefore not much larger than its tombstone. The larger tomb of the Petřvald family (2), with a maximum estimated size of approximately $3.7 \times 3 \mathrm{~m}$, is in the area of the southern arm of the cross.

The old tomb of the Berchtold family was found (4) with a possible plan of approximately $3 \times 3.5 \mathrm{~m}$ at the eastern side of the existing building.

There is an entrance into the currently ruined tomb of the Petrvalds (3) in the central part of the investigated building. On the basis of the correlation of possible relics of masonry (M) in the central part of the chapel, we assume the possible existence of a smaller building sized ca $6.5-7 \mathrm{~m} \mathrm{x} 4.5-5 \mathrm{~m}$ (the maximum wall thickness is $1.0 \mathrm{~m}$ ).

A possible secondary grave ( $G$ ?) or increased proportion of gross landfill material cannot be excluded at the western edge of the interpreted linear inhomogeneity.
Additional local "anomalies" in the area of the investigated building (Fig. 5, 6) are either part of the original defunct building, or are linked to its potential progress.

\section{Visual survey}

\section{The tomb of the Petřvald family}

The tomb is located in the southern part of the chapel. It consists of a rectangular funeral chamber, measuring approximately $3 \times 3.70 \mathrm{~m}$, with a barrel vault (with the axis in the north - south direction). The entrance to the burial chamber was from the north. There was a staircase which is hidden under the tombstone in the chapel floor. The tomb is ventilated by a vent window in the eastern wall of the chapel. The exploratory probe was inserted into the tomb through this window. The tomb walls are covered with whitish plaster. A huge stone sarcophagus stands inside the burial chamber. Human skulls are secondarily deposited on its lid. The remainder of the space is primarily filled with the planks of disintegrated wooden 


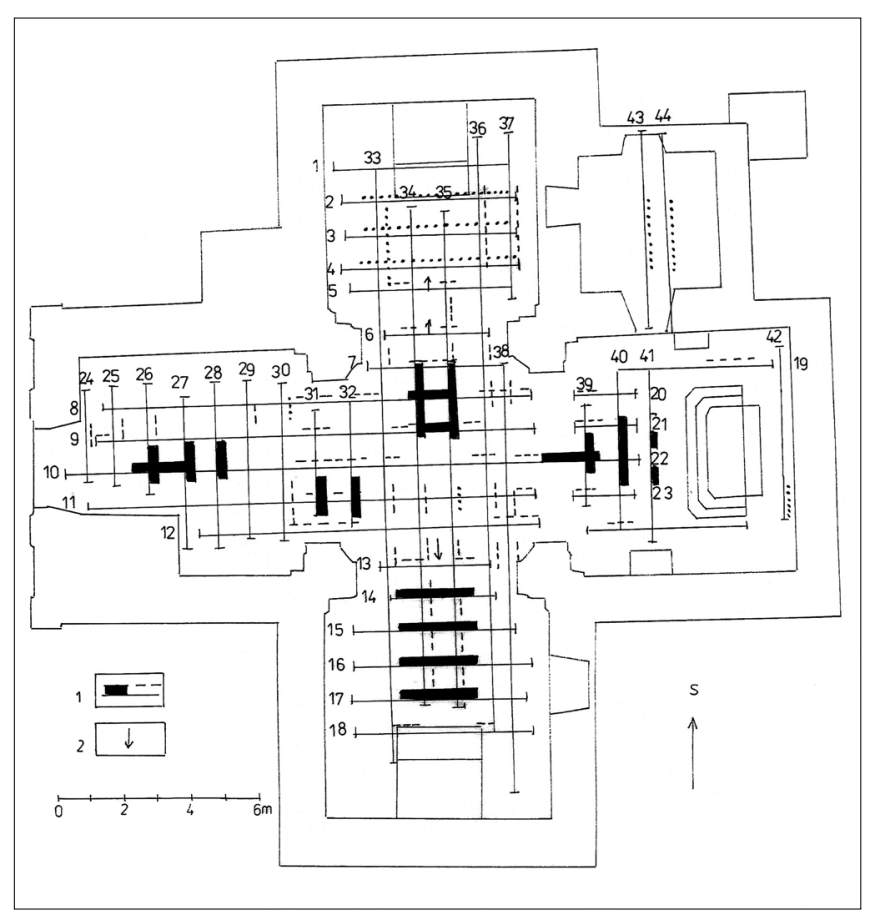

Fig. 5. Buchlov - the Chapel of St. Barbara: correlation diagram of the inhomogeneities based on the GPR method. 1 - near-surface inhomogeneities ranged according to their expressiveness; 2 - depression structures

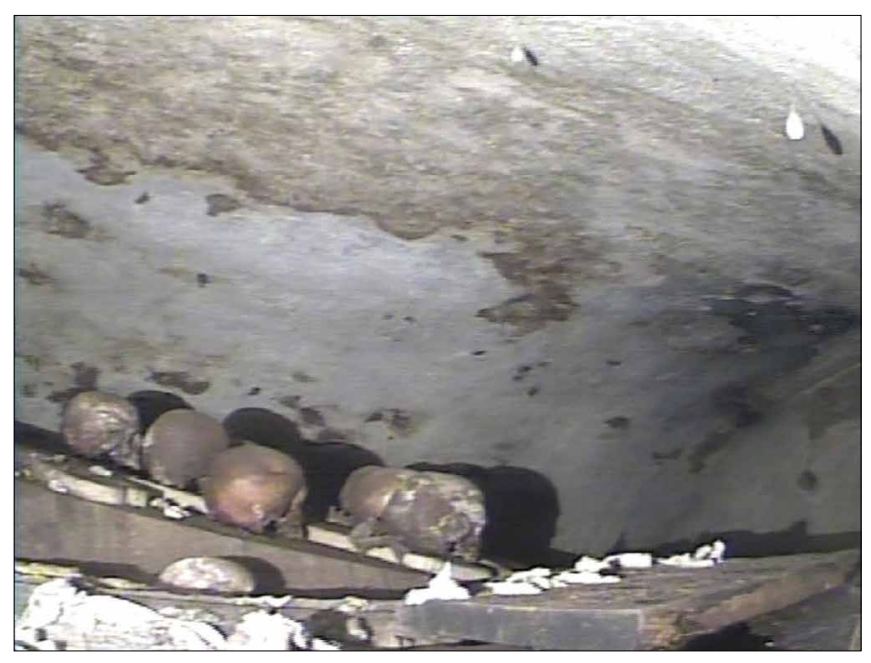

Fig. 7. Buchlov - the Chapel of St. Barbara, the tomb of the Petřvald family (skulls on the stone sarcophagus lid, two spider cocoons on the ceiling).

coffins, skeletal remains, debris and garbage (Figure 7). An interesting detail is a relatively large amount of spiders cocoons on the ceiling of the burial chamber. They are in all probability cocoons of the Meta menardi (European cave spider) species.

\section{The old tomb of the Berchtold family}

The tomb is located under the eastern part of the chapel. It consists of a rectangular burial chamber, measuring ca $3 \times 3.6 \mathrm{~m}$, with a barrel vault (the axis of the vault in the east - west direc-

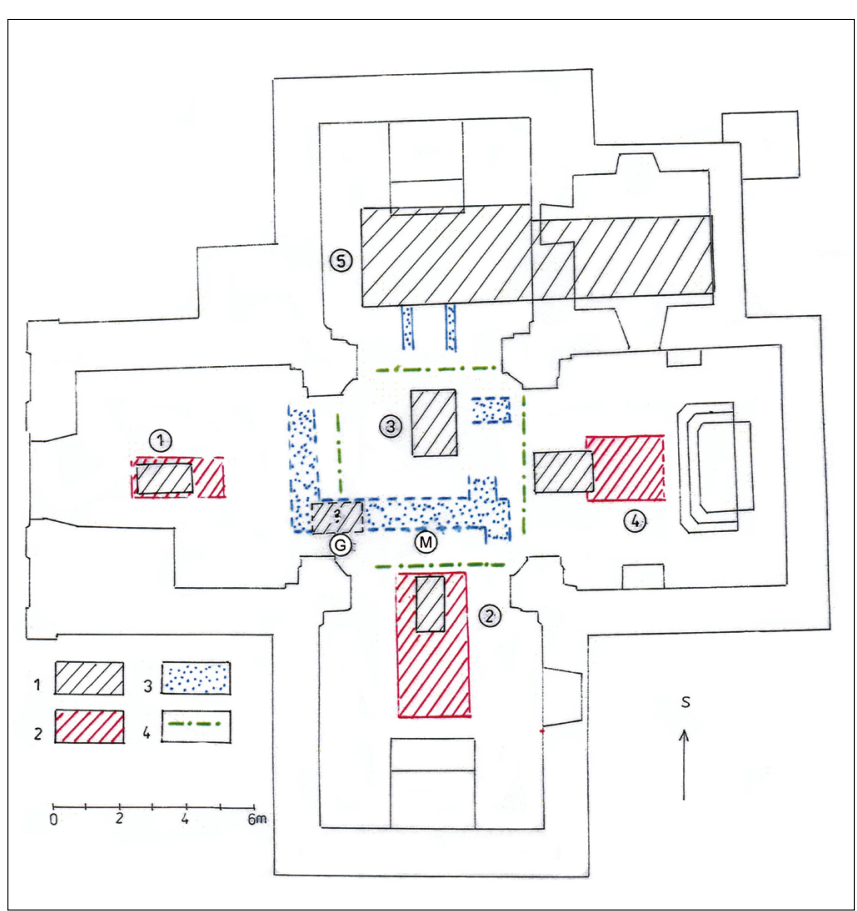

Fig. 6. Buchlov - the Chapel of St. Barbara: archaeological interpretation of the results of the geophysical measurements. 1 - entrances to the tombs, the tomb; 2 - the estimated sizes of the tombs; 3 - any relics of masonry; 4 - a step

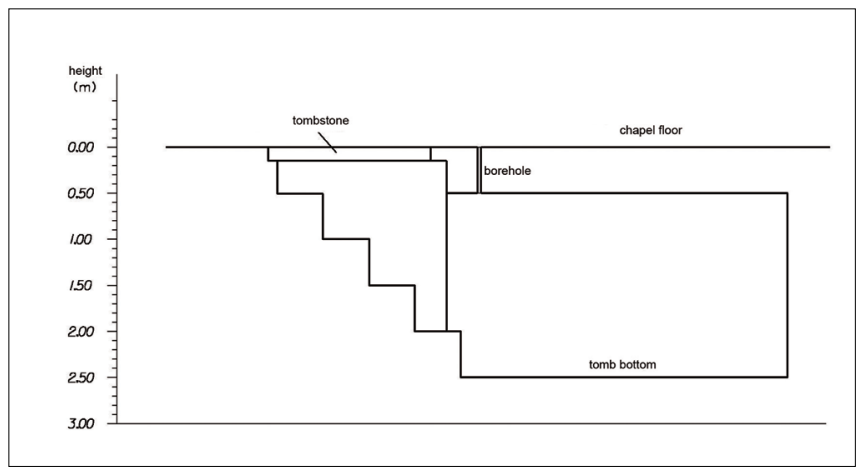

Fig. 8. Buchlov - the Chapel of St. Barbara. Longitudinal section (east - west) of the old tomb of the Berchtold family.

tion). The entrance into the tomb consists of a narrow (ca $1 \mathrm{~m}$ ) gangway with a brick staircase (5 steps), covered by a tombstone at the floor level of the chapel (Fig. 8). The walls of the tomb are covered with whitish plaster while the floor is made of square tiles. A total of 7 burials were identified in the eastern part of the burial chamber. They are placed in three metal and four wooden coffins. The metal coffins do not stand directly on the floor, but on wooden beams. The two wooden coffins stand directly on the floor on turned legs (Fig. 9). Two more wooden chests, significantly smaller, are placed on their lids. They apparently belong to children. The exploratory probe captured and photographed authenticas on two of the metal coffins (placed on one other). Both authenticas were legible, therefore these coffins can be identified as the burials of Sigismund I. Berch- 


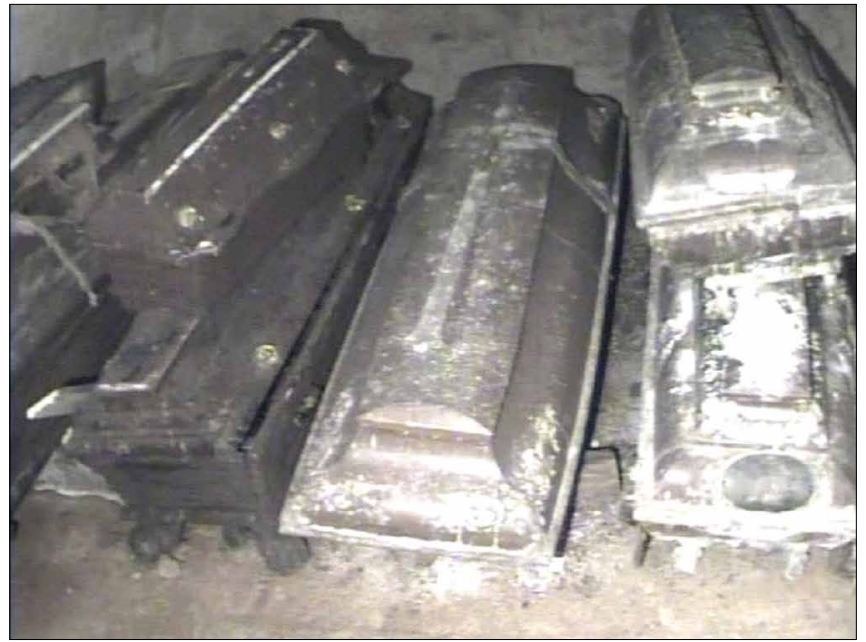

Fig. 9. Buchlov - the Chapel of St. Barbara, the old tomb of the Berchtold family - view of the coffins in the eastern part.

told (1799-1869) (Fig. 10) and his wife Ludmila Berchtold, née Vratislav, of Mitrovice (1808-1869). Another authentica has been identified and partly read on a wooden coffin by the north tomb wall. The chest can consequently be recognised as the burial of Leopold Franz Xaver Berchtold (1759-1809).

\section{CONCLUSION}

Non-destructive research with a georadar (GPR) was conducted with the investigation of a number of the detected objects with a camera system in the interior of the chapel of St. Barbara on Modla hill in the cadastral district of Buchlovice in 2011-2012.

The results of the geophysical works indicated the existence of various planar and linear subsurface inhomogeneities, which can mainly be assigned to uncaved brick-stone tombs of varying sizes and depths, belonging to some of the estate owners of the Berchtold and Petřvald families. Additional discovered inhomogeneities in all probability represent relics of masonry of the original medieval chapel located in the central part of the building.

A visual survey of the tombs provided extremely detailed information regarding the appearance and condition of the two underground tombs, the tomb of the Petřvald family and the old tomb of the Berchtold family. While minimizing financial and time resources, information about the condition of the inaccessible underground was obtained, which will primarily be of use to the monument administrator in deciding how to dispose of the site and how to further secure and protect it. As demonstrated by the results of both methods applied, this choice demonstrated the suitability of their use in addressing issues of funeral structures and relics of masonry of older torn-down sanctuaries, even in the interiors of modern-age church buildings without physical probing and areal archaeological excavations.

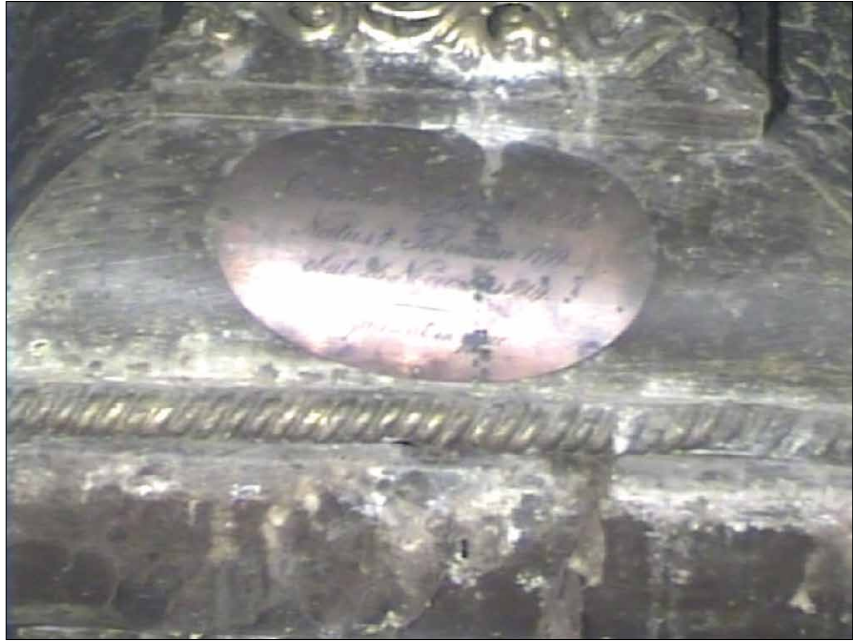

Fig. 10. The authentica on the coffin of Sigismund I. Berchtold ( $† 1869)$ photographed in the old tomb of the Berchtold family in the chapel of St. Barbara.

\section{REFERENCES}

Czudek, T. (1973): Geomorfologické členění ČR. Studia geographica 23. NČSAV, Praha.

Hašek, V. (1999): Methodology of Geophysical Research in Archaeology. BAR, Oxford.

Hašek, V. - Glisníková, V. (2005): Anteil der geophysikalischen Methoden an der archäologischen Erforschung der unterirdischen Räume. Slovenská archeológia, LIII, 337-362.

Hašek, V. - Šindelár, J. - Thomová, Z. - Tomešek, J. (2008): Nedestruktivní průzkum kostela sv. Víta v Českém Krumlově. Ve službách archeologie, $1 / 08,55-63$.

Hašek, V. - Tomešek, J. (2011): Zpráva o archeogeofyzikální prospekci na akci k.ú. Buchlovice, kaple sv. Barbory. MS Isolines s.r.o., Brno.

Hašek, V. - Unger, J. (1997): Geophysical and Archaeological Research of Medieval Architecture of the Thirteenth to Fiffeenth Centuries in Moravia. Archaeological Prospection, 5, 1-28, Bradford.

Hašek, V. - Unger, J. (2001): Geophysikalische Prospektion und archäologische Untersuchung von mittelalterlichen Befestigten Siedlungen Mährens. Przegląd Archeologiczny, 49, 103-126.

Hašek, V. - Unger, J. (2005): Geophysikalische Prospektion und archäologische Forschung in mährischem Kirchen. Beiträge zur Mittelalterarchäologie in Österreich, 21, 297-311.

Hašek, V. - Unger, J. (2010): Religions Architecture in the Czech Republic in the Light of geophysical Prospection and Archaeological Excavation. BAR IS 2128, Oxford.

Hrdý, M. - Kořínek, V. - Žižlavský, B. (2005): Moje Buchlovice. Obec Buchlovice.

Chlupáč, I. et al. (2011): Geologická minulost České republiky. Academia, Praha.

Maříková-Kubková, J. et al. (2005): Předběžná zpráva o průzkumu staré královské hrobky v chóru sv. Víta na Pražském hradě, Castrum Pragense, 6, 99-123.

Samek, B. (1994): Umělecké památky Moravy a Slezska, A/I. Academia, Praha.

\section{AUTHORS}

RNDr. Vladimír Hašek, DrSc.

Isolines, spol. s r.o., Došlíkova 3, 63600 Brno,

E-mail: hasek.vladimir@gmail.com 
Mgr. Tomáš Mořkovský

Dep. of Anthropology, Faculty of Science, Masaryk university, Vinařská 5, 60300 Brno

E-mail: tmorkovsky@email.cz

Jiř́ Šindelář

Naše historie, o.s., Měšická 1724, 39002 Tábor

E- mail: geo@geo-cz.com
Jan Tomešek

Isolines, spol. s r.o., Došlíkova 3, 63600 Brno,

Email: isolines@isolines.cz 